\title{
Upwelling areas do not guarantee refuge for coral reefs in a warming ocean
}

\author{
Iliana Chollett ${ }^{1,2, *}$, Peter J. Mumby ${ }^{1,2}{ }^{\text {, Jorge Cortés }}{ }^{3}$ \\ ${ }^{1}$ Marine Spatial Ecology Lab, Hatherly Laboratory, School of Biosciences, University of Exeter, Prince of Wales Road, \\ Exeter EX4 4PS, UK \\ ${ }^{2}$ Marine Spatial Ecology Lab, School of Biological Sciences, University of Queensland, St. Lucia, Queensland 4072, Australia \\ ${ }^{3}$ Centro de Investigación en Ciencias del Mar y Limnología, and Escuela de Biología, Universidad de Costa Rica, San Pedro, \\ 11501-2060 San José, Costa Rica
}

\begin{abstract}
Global warming is a severe threat to coral reefs. It has been proposed that upwelling could minimise the thermal stress caused by ocean warming, and therefore upwelling areas may serve as a refuge for corals. Here, using $21 \mathrm{yr}$ of satellite sea surface temperature data, we analysed the degree to which the thermal stress experienced by corals is reduced in 4 seasonal upwelling areas with reef development: Colombia in the southern Caribbean, Panama in the eastern tropical Pacific, Oman in the Arabian Sea and Madagascar in the Indian Ocean. Upwelling areas do not always offer protection from thermal stress. When compared with nearby non-upwelling areas, upwelling can only provide defence against warming events if: (1) the threat and the upwelling coincide, and (2) this overlap produces a meaningful decrease in thermal stress in upwelling areas. These conditions were met in only 2 of the 4 upwelling areas analysed: Colombia and Oman. In Oman, upwelling decreased the magnitude, frequency and duration of thermal disturbances (identified when Coral Bleaching HotSpots, anomalies exceeding the average temperature of the warmest month, are larger than $1^{\circ} \mathrm{C}$ ), while in Colombia upwelling only decreased their frequency. The protective role of upwelling seems to be limited geographically; therefore, further upwelling areas need to be assessed individually in order to evaluate their capacity as a refuge from thermal stress.
\end{abstract}

KEY WORDS: Coral reef · Upwelling · Bleaching - Climate change - Sea surface temperature • AVHRR

\section{INTRODUCTION}

In the last $100 \mathrm{yr}$, global air temperature has increased $0.74^{\circ} \mathrm{C}$ (IPCC 2007), and the rate of temperature change is 2 to 3 times higher than has been observed over the past $420000 \mathrm{yr}$ (Hoegh-Guldberg et al. 2007). Although land has warmed faster than the oceans, over $80 \%$ of the heat added to the climate system has been absorbed by the sea, the average temperature having increased by approximately 0.14 to $0.18^{\circ} \mathrm{C}$ per decade during the last $20 \mathrm{yr}$ (Casey \& Cornillon 2001, Good et al. 2007, IPCC 2007). These facts have prompted concern that rising seawater temperatures could increase the frequency and severity of coral bleaching events and the irreversible decline of coral reef ecosystems (West \& Salm 2003, McWilliams et al. 2005, Hoegh-Guldberg et al. 2007, Wilkinson \& Souter 2008).

The rise of thermal stress on coral reefs has led to speculation that coral-dominated systems may become increasingly restricted to locations of naturally low thermal and/or radiative stress (Glynn 1996, Salm \& Coles 2001, Riegl \& Piller 2003, West \& Salm 2003, Grimsditch \& Salm 2005, Baker et al. 2008). These areas could provide 'pockets of resistance' (sensu West \& Salm 2003), not by increasing the physiological tolerance of the inhabiting corals, but by providing extrinsic environmental conditions that reduce the stressful conditions. Regions of relatively low thermal and radiative stress include upwelling systems (Riegl 
2003), deep water areas of strong vertical mixing (Skirving et al. 2006) and sites with high water flow (Nakamura \& van Woesik 2001, Nakamura et al. 2003) or high levels of shading (Mumby et al. 2001, Fabricius et al. 2004). Although these areas could constitute a refuge from bleaching, they have other features that could dampen reef development. For example, upwelling areas can be subjected to cold thermal stress (Glynn et al. 1983), deep areas may host poorly connected reefs (Bongaerts et al. 2010), and high flow can dislodge corals (Madin \& Connolly 2006).

The present analysis focuses on just one of the potential sources of cool water on reefs: seasonal upwelling. Upwelling, the upward motion of subsurface water towards the surface, is an oceanographic phenomenon that decreases sea temperature and increases the nutrient concentration in coastal waters (Sverdrup et al. 1942). Lower incidences of coral bleaching and associated mortality have been related to the influence of upwelling in the Gulf of California (Reyes-Bonilla 2001), Mexico (Glynn \& Leyte-Morales 1997), Costa Rica (Jiménez et al. 2001), Panama (Glynn et al. 2001), Venezuela, Colombia (Rodríguez-Ramírez et al. 2008), South Africa (Riegl 2003) and northern Madagascar (McClanahan et al. 2007). Seasonal upwelling (as opposed to occasional upwelling) constitutes a persistent feature in time that has the potential to decrease the effects of thermal stress in a predictable manner (West \& Salm 2003). Given the evidence listed above, seasonal upwelling areas have been proposed as possible refugia in a warming ocean, and therefore desirable locations for the establishment of marine protected areas (West \& Salm 2003). However, some empirical evidence suggests that the ability of upwelling to prevent bleaching is not consistent over time: during the 1982-83 El Niño-Southern Oscillation (ENSO), upwelling was incapable of offsetting the warming of the water masses in Pacific Panama. Sea surface temperatures (SSTs) in the upwelling area of the Gulf of Panama matched those found in the non-upwelling area of the Gulf of Chiriquí, and coral mortality reached $84.7 \%$ in the former (Glynn et al. 1988).

Since upwelling and severe warming are seasonal and interannually variable phenomena (Astor et al. 2003, Philander \& Fedorov 2003, Wang \& Fiedler 2006, Wilkinson \& Souter 2008, Bograd et al. 2009), their temporal variability needs to be considered in order to provide a more systematic analysis of the role of seasonal upwelling in preventing mass bleaching events. In this paper we assess the capability of upwelling to offset warming of the water masses using long-term temperature records. The use of long time series allows the evaluation of thermal patterns over continuous scales rather than confining the analysis to particular time periods that represent snapshots in time. Upwelling would offset bleaching only if (1) upwelling and severe warming events occur at the same time and (2) upwelling provides sufficient cooling to reduce the thermal stress experienced at the location. We examined the first prerequisite by determining the synchrony of upwelling and warming events in 4 regions of the globe. We then examine the second prerequisite, that upwelling reduces stress, by carefully examining the impacts of upwelling on the magnitude, frequency and duration of thermal anomalies within each region (i.e. by comparing the stress in upwelling and nearby non-upwelling areas).

We stress that our analysis is confined to the effects of upwelling on the temperature experienced by corals and excludes other potentially beneficial impacts of upwelling associated with reduced light penetration or increased heterotrophic feeding by corals during plankton blooms that might be associated with upwelling events. Reduced light has the potential to decrease, or even prevent, bleaching (Lesser \& Farrell 2004, Enríquez et al. 2005), and enhanced heterotrophy has the potential to offset trophic stress associated with a paucity of symbionts (Grottoli et al. 2006, Houlbrèque \& Ferrier-Pagès 2009). Unfortunately, it is currently not possible to generalise the potential impacts of these effects because of the lack of accurate models of the interactions between thermal stress, radiative stress and heterotrophic plasticity.

\section{MATERIALS AND METHODS}

Data source and study locations. Weekly SST data for 1985 to 2005 were derived from the $4 \mathrm{~km}$ resolution Advanced Very High Resolution Radiometer (AVHRR) Pathfinder dataset (Casey et al. 2010). The data were collected and processed by the National Oceanographic Data Center in cooperation with the University of Miami, and the weekly product used was provided by the National Oceanic and Atmospheric Administration (NOAA) Coral Reef Watch program.

Using the $21 \mathrm{yr}$ dataset, we examined the timing of upwelling and bleaching-like conditions in 4 regions of the world, with representation from all 3 tropical oceans. In each region, an upwelling area and a neighbouring non-upwelling area that contained coral communities were delineated. Reefs subjected to seasonal upwelling were first located based on previous research (Glynn 1993, Glynn et al. 2001, Díaz-Pulido \& Garzón-Ferreira 2002, McClanahan et al. 2009). Subsequently the nearest non-upwelling reef, based on the United Nations Environment Programme-World Conservation Monitoring Centre (UNEP-WCMC) Biodiversity Map Library, was chosen for comparison. The 
regions were (a) Colombian Caribbean at Tayrona National Park (NP; an upwelling area, $11.5^{\circ} \mathrm{N} 74.2^{\circ} \mathrm{W}$ ) and Rosario NP (a nearby non-upwelling area, $10.2^{\circ} \mathrm{N}$ $\left.75.8^{\circ} \mathrm{W}\right)$, (b) Pacific Panama at the Gulf of Panama (upwelling, $7.5^{\circ} \mathrm{N} 79.0^{\circ} \mathrm{W}$ ) and the Gulf of Chiriquí (non-upwelling, $8.0^{\circ} \mathrm{N} 82.0^{\circ} \mathrm{W}$ ) (c) Oman at Sûr

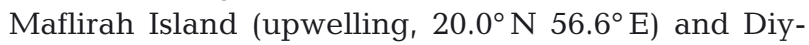
maaniyat Islands (non-upwelling, $23.9^{\circ} \mathrm{N} 58.1^{\circ} \mathrm{E}$ ) and (d) northern Madagascar at Cap d'Ambre (upwelling, $12.0^{\circ} \mathrm{S} 49.0^{\circ} \mathrm{E}$ ) and Nosy be Island (non-upwelling, $13.1^{\circ} \mathrm{S} 48.2^{\circ} \mathrm{E}$; Fig. 1). We briefly describe the upwelling and bleaching regime in each region below.

The Colombian Caribbean is characterised by strong upwelling along its north coast (Andrade \& Barton 2005). Upwelling occurs at the beginning of the year because of the increase in the strength of the winds due to the latitudinal migration of the Intertropical Convergence Zone (Andrade \& Barton 2005, Amador et al. 2006, Wang 2007). Additionally, the influence of the Caribbean Low-Level Jet produces a secondary intensification of winds, and thus upwelling, during summer (Wang 2007). On the other hand, bleaching in the Caribbean has been reported during summer months when incoming solar radiation is at its maximum (Wilkinson \& Souter 2008).

Upwelling in the Gulf of Panama occurs also at the beginning of the year due to the migration of the Intertropical Convergence Zone (Amador et al. 2006).
In the eastern tropical Pacific, warming disturbances are associated with ENSO events, with temperature anomalies typically lasting from March to September of the following year, and with a mature phase of stronger anomalies from November to January (Wang \& Fiedler 2006).

In Oman, the southwest monsoon produces winddriven upwelling off the east coast during summer (Shi et al. 2000). Anomalously high SSTs in this region have been attributed to unusual warming during the summer months, occasionally linked to ENSO events (Wilkinson et al. 1999).

Unlike the other upwelling areas described, upwelling in Madagascar is not forced by winds, but by currents. The South Equatorial current produces upwelling at the northern and southern tips of Madagascar (McClanahan et al. 2009). This current shows no obvious seasonal variation, and exhibits high stability all year round (Sætre 1985). As in Oman, unusually warm conditions in Madagascar tend to occur in summer and have been linked to ENSO events (McClanahan et al. 2007).

Identifying upwelling and warming events. Using the weekly dataset, upwelling conditions were identified when temperatures in an upwelling area fell 3 standard deviations (SD) below the monthly average temperature experienced in the same month in a neighbouring, non-upwelling area. Temperatures below

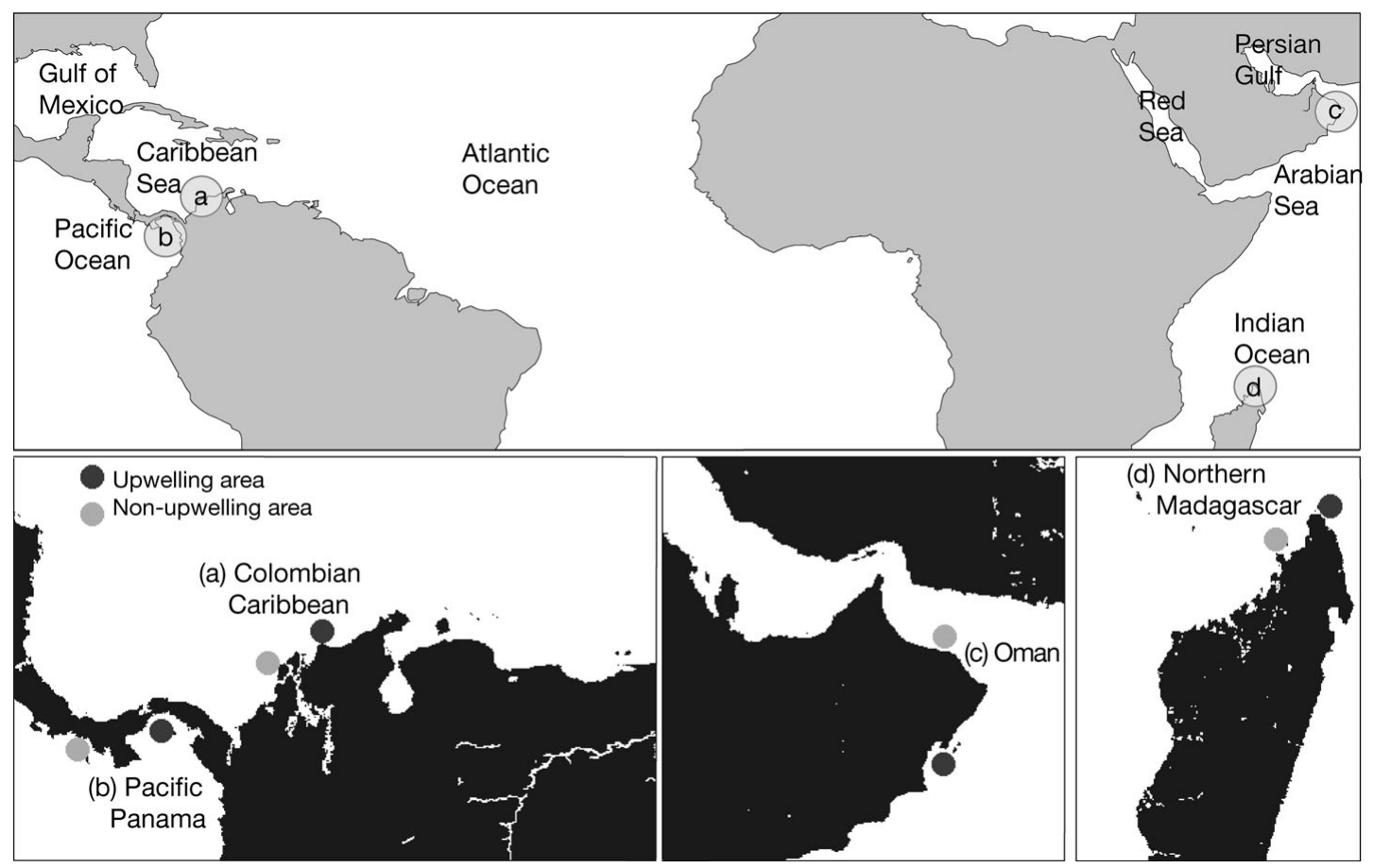

Fig. 1. Assessed regions in (a) Colombian Caribbean, (b) Pacific Panama, (c) Oman and (d) northern Madagascar. Upwelling areas are shown in dark gray and non-upwelling areas in light gray 
this threshold are likely to belong to a different statistical population (Zar 1999). This index provides a simple proxy to identify upwelling conditions, when waters are significantly colder than in the surrounding areas.

Conversely, HotSpot anomalies (Liu et al. 2006) were used to identify warming conditions that may produce bleaching. HotSpots measure the difference between the recorded temperature and the average temperature of the hottest month at that location. Only positive values are derived, since HotSpots were designed to measure positive thermal stress (Liu et al. 2006). In this study, only HotSpots larger than $1{ }^{\circ} \mathrm{C}$ were used to indicate excessive thermal stress. Previous studies have found that corals are acclimated to local conditions (Coles et al. 1976, Coles \& Jokiel 1977, Goreau \& Hayes 1994, Brown et al. 1996, Castillo \& Helmuth 2005, Ulstrup et al. 2006), and temperatures of $1^{\circ} \mathrm{C}$ above local seasonal maxima are enough to cause stress (Strong et al. 1997, Goreau et al. 2000, Liu et al. 2006). HotSpots were chosen over accumulated measures of stress such as Degree Heating Weeks (Liu et al. 2006) because the instantaneous coincidence of upwelling and warming needed to be assessed.

Data were collected within a region of $256 \mathrm{~km}^{2}(16 \times$ 16 pixels) around each location of upwelling or nonupwelling. This area is small enough to prevent contamination of upwelling and non-upwelling areas, yet large enough to provide a good sample size for statistical analyses. Homogeneity of each $256 \mathrm{~km}^{2}$ area was verified by computing the local mean and the variance using sliding windows of varying sizes (Fortin \& Dale 2005).

Prerequisite 1: Synchrony of upwelling and warming events. To estimate the temporal overlap of upwelling and warming conditions, the probability of occurrence of upwelling events was calculated and compared to the incidence of severe warming episodes in the region. For the entire weekly dataset, upwelling and warming events were identified using the metrics described above. Upwelling conditions were identified in each of the 4 upwelling areas. Severe warming conditions typically affect extensive areas (Baker et al. 2008, Wilkinson \& Souter 2008), but the ability to detect their signal (HotSpots) in a given month changes among locations within a region. Because HotSpots are more likely when temperatures are close to the seasonal maximum, but given that the timing of the hot season changes among locations, areas with differing thermal regimes should be assessed to obtain a comprehensive estimate of the occurrence of severe warming. This is why in the present study, warming conditions were said to occur in a region if HotSpots were found in either the upwelling or non-upwelling areas. Moreover, by allowing warming to be identified within upwelling areas, this approach is consistent with studies that have demonstrated local acclimation of corals to temperature and the occurrence of bleaching once temperature anomalies are experienced (e.g. Glynn \& D'Croz 1990, D'Croz et al. 2001).

Each month of the time series was categorised as having an upwelling and/or HotSpot event if at least one week of the month was positive for the respective event. Using this monthly information, the number of times upwelling $\left(\mathrm{F}_{\mathrm{u}}\right)$ and warming $\left(\mathrm{F}_{\mathrm{w}}\right)$ were present in a given month was calculated for the entire time period (over $21 \mathrm{yr}$ ), in addition to the joint occurrence of the 2 events $\left(\mathrm{F}_{\mathrm{u} \cap \mathrm{w}}\right)$. This allowed independent monthly estimates of the frequency of each type of event to be obtained and their intersection in each region. The monthly incidence was then converted into the statistical likelihood of an event occurring in any given year using a binomial distribution. To allow clear comparisons to be drawn among regions, we standardised our results by dividing the joint probability of warming and upwelling $\left(\mathrm{P}_{\mathrm{u} \cap \mathrm{w}}\right)$ by the warming probability $\mathrm{P}_{\mathrm{w}}$ (i.e. giving the proportion of warm periods for which upwelling also occurs). We call this value $\left(\mathrm{P}_{\mathrm{u} \cap \mathrm{w}} / \mathrm{P}_{\mathrm{w}}\right)$ 'standardised joint occurrence' throughout the text.

The timing of warming and upwelling events found in our work coincide with temporal patterns previously reported for the studied areas (Sætre 1985, Wilkinson et al. 1999, Shi et al. 2000, Andrade \& Barton 2005, Amador et al. 2006, Wang \& Fiedler 2006, Wilkinson \& Souter 2008), which confirms the appropriateness of the metrics used to quantify these events.

Prerequisite 2: Reduction of thermal stress by upwelling. The co-occurrence of severe warming events and upwelling is not enough to identify an area as a meaningful refuge; upwelling should also translate into a milder thermal disturbance regime in that area. Three elements should be considered when assessing the impact of stressful events on biological systems: the intensity or magnitude of the disturbance, the duration of individual stress episodes and the temporal frequency of different episodic events (Connell 1978, Pickett \& White 1986). Following this categorisation, if upwelling can provide refuge from warming, then upwelling areas would be characterised by smaller thermal anomalies, shorter anomalous periods and/or fewer anomalous episodes in the long term when related to nearby, non-upwelling reefs.

To gain some insight into the overall effect of upwelling on decreasing thermal stress in an area, the long-term stress undergone in the last $21 \mathrm{yr}$ (1092 wk) by the 4 regions assessed was quantified. Anomalous events were again identified when HotSpots were larger than $1^{\circ} \mathrm{C}$. Using the weekly data, the magnitude of HotSpots, the duration of the anomalous episodes (when HotSpots were registered in contiguous weeks) 


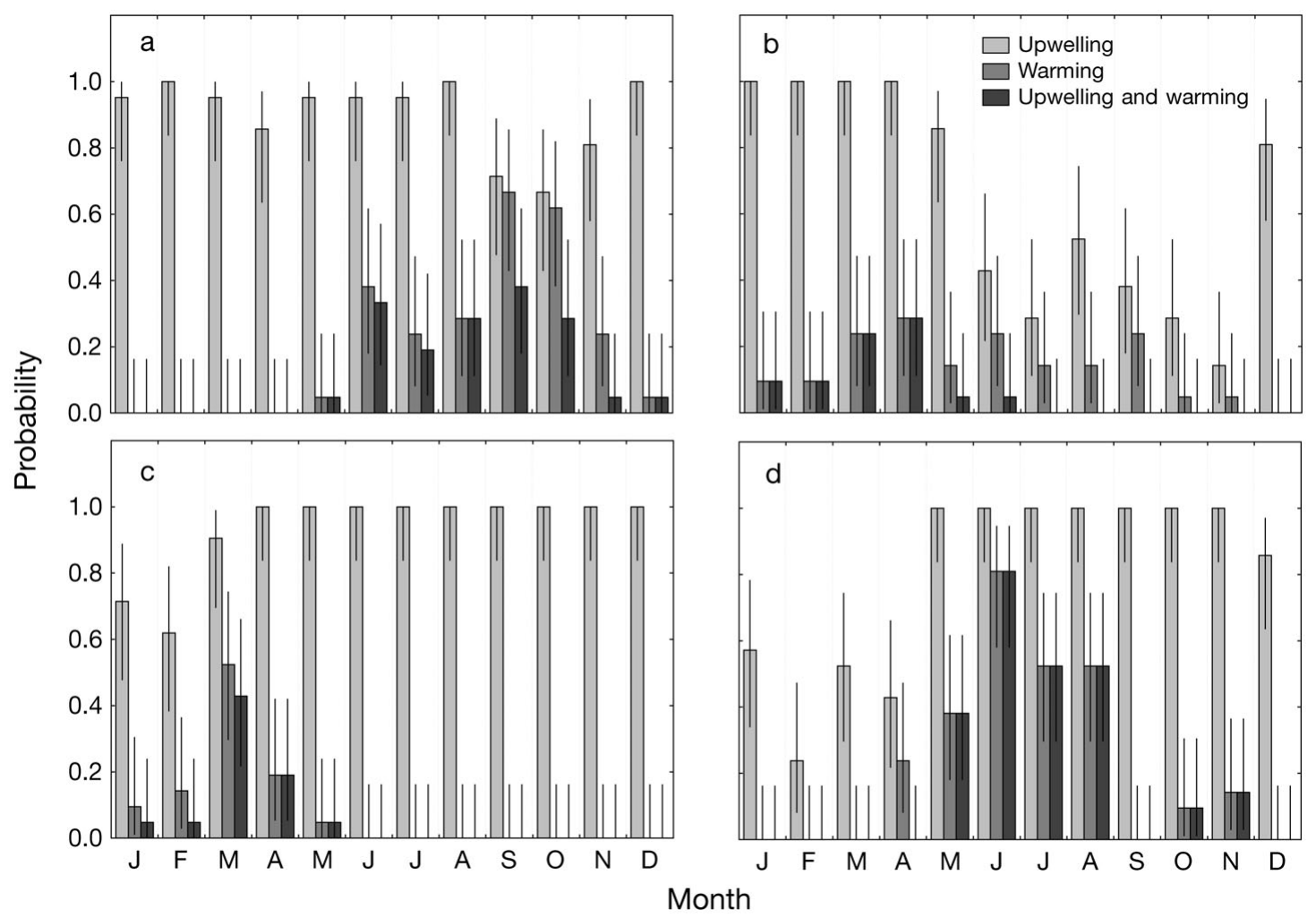

Fig. 2. Probability of occurrence of upwelling and warming events, as well as their joint incidence in (a) Colombian Caribbean, (b) Pacific Panama, (c) Oman and (d) northern Madagascar. Warming events were identified when HotSpots in the region (considering upwelling and adjacent non-upwelling areas) exceeded $1^{\circ} \mathrm{C}$. Upwelling conditions were identified when temperatures in upwelling areas were 3 SD below the monthly average temperature experienced in the same month in a neighbouring nonupwelling area. Probabilities were calculated from monthly incidence of upwelling/warming conditions in 21 yr; whiskers indicate $95 \%$ confidence intervals (1985 to 2005 AVHRR Pathfinder data)

and the total frequency of discrete anomalous events was calculated for the entire dataset in upwelling and non-upwelling areas in each of the regions (Fig. 2). For each region, upwelling and non-upwelling disturbance estimates were then compared using 1-tailed tests ( $t$-tests and $Z$-test for 2 proportions). To reduce a potential influence of spatial autocorrelation, only random subsets of $30 \%$ of the delineated areas were used, and a bootstrap procedure (1000 iterations) was used to compute average statistics and their SE.

\section{RESULTS}

\section{Prerequisite 1: Synchrony of upwelling and warming events}

Warming events occurred during the summer months in the Colombian Caribbean, Oman and Northern Madagascar (Fig. 2a,c,d) but year-round in Pacific Panama (Fig. 2b). In the southern Caribbean and the eastern tropical Pacific, upwelling occurred at the be- ginning of each year. The temperature decrease was acute in the eastern tropical Pacific, but the cooling lasted longer in the southern Caribbean (Fig. 2a,b). This implies that the capability of upwelling to counteract bleaching conditions is greater in the Caribbean, where there is larger co-occurrence of seasonal cooling of water masses and episodic warming. In this region, the average of the standardised joint occurrence was 0.74 . This implies that $74 \%$ of the time, when warming was present, upwelling was also present. In the Pacific, thermal anomalies can occur in any month, so upwelling would be able to offset warming only during the short cooling season. Thus, given the limited duration of upwelling, the average of the standardised joint occurrence of the 2 events in this area was only 0.41 . Upwelling off the east coast of Oman was active during summer, which coincides with the occurrence of warm anomalies (Fig. 2c). Upwelling therefore counteracted warming events during most of their duration, and the average of the standardised joint occurrence was 0.86 . In Madagascar, upwelling occurred all year round. Consequently, upwelling decreased the temperature of 
the water most of the year, and the average of the standardised joint occurrence was $73 \%$ (Fig. 2d).

In summary, the average of the standardised joint occurrence of warming and upwelling conditions was generally moderate to high ranging from $41 \%$ in Tropical Eastern Pacific to 73, 74 and $86 \%$ in Madagascar, the southern Caribbean and Oman, respectively.

\section{Prerequisite 2: Reduction of thermal stress by upwelling}

When comparing the thermal disturbance regime in upwelling and nearby non-upwelling areas, upwelling did not decrease the magnitude of the thermal anomalies, the duration or the frequency of the anomalous periods in the eastern tropical Pacific or northern Madagascar (1-tailed Student's $t$-test, $\mathrm{p}>0.05$ for all contrasts). In contrast, upwelling in Colombia provided a significant reduction in the frequency of anomalous periods, decreasing the total occurrence of disturbance events by $12 \%$ (1-tailed $Z$-test for 2 proportions, mean \pm SE: $Z=-3.55 \pm 0.03, \mathrm{p}<0.05)$.

Oman is the only case study analysed in which upwelling was able to reduce the 3 measures of thermal stress, decreasing the magnitude of the thermal anomalies (by $4 \%$ ), the duration (by $24 \%$ ) and frequency (by $55 \%$ ) of disturbance events when compared to neighbouring non-upwelling areas $(t$-tests and 1-tailed $Z$-test for 2 proportions, $t=-9.67 \pm 0.02, t=$ $-10.39 \pm 0.03, Z=-23.91 \pm 0.02, \mathrm{p}<0.05)$.

\section{Net outcomes of synchrony and impact on thermal stress}

Our results led to 3 distinct outcomes for the 4 upwelling areas analysed: (1) synchrony of upwelling and warming and significant reduction of stress in Colombia and Oman; (2) partial synchrony of upwelling and warming events and no reduction of thermal stress in the eastern tropical Pacific; and (3) synchrony but no reduction of stress in northern Madagascar.

To understand the net outcomes of variable synchrony and impact on thermal stress, the monthly frequencies of HotSpots were disaggregated for each area (upwelling and non-upwelling) within each of the regions assessed (Fig. 3). In both upwelling and nonupwelling areas, warming conditions were more likely when water temperatures were closer to the maximum monthly climatological mean of the location.

In Colombia, the temporal overlap between upwelling and warming conditions at the beginning of summer due to the influence of the Caribbean Low- level Jet (Wang 2007) reduced the length of the warm season in upwelling areas by approximately 4 mo in comparison to nearby non-upwelling areas (Fig. 3a). The shortened warm season translates into a shorter period of vulnerability to thermal stress, and a lower frequency of thermal disturbance events (decrease of $10 \%)$. In this region of the southern Caribbean, upwelling may indeed provide a refuge from warming.

In the Gulf of Oman, upwelling occurred at the peak of the warm season and provided cooler conditions than in nearby non-upwelling areas. Upwelling decreased the maximum monthly mean by $2.3^{\circ} \mathrm{C}$ and punctuated the warm season, decreasing its total length by $1 \mathrm{mo}$. In this way, upwelling weakened and shortened the warm period, reducing the incidence of thermal anomalies by $54 \%$. In Oman, therefore, upwelling can provide effective protection against severe warming.

Warm seasons did not coincide in upwelling and nonupwelling areas of the eastern tropical Pacific (Fig. 3b). Maximum incoming solar radiation occurs during the boreal winter in this region (Amador et al. 2006). This results in warmer waters in non-upwelling areas, but not in upwelling areas, where upwelling decreases the temperature of the waters and delays the onset of the warm season. As ENSO disturbances are possible all year, and upwelling does not decrease the length of or weaken the warm season, both upwelling and nonupwelling locations are equally vulnerable to thermal disturbances. Additionally, sporadic ENSO events produce both a strengthening of the thermal anomalies and the weakening of the upwelling, further decreasing the significance of upwelling as a protection in the eastern tropical Pacific.

In Madagascar, the South Equatorial Current (McClanahan et al. 2009) reduces temperatures throughout the year. The seasonal temperature patterns in upwelling and non-upwelling areas were almost indistinguishable (Fig. 3d): summers were equally long, the period of vulnerability to anomalies was similar, and consequently upwelling offers no significant protection from thermal stress.

\section{DISCUSSION}

While there is evidence that upwelling has helped reduce the effects of bleaching at particular locations and times (Glynn \& Leyte-Morales 1997, Glynn et al. 2001, Jiménez et al. 2001, Podestá \& Glynn 2001, ReyesBonilla 2001, Reyes-Bonilla et al. 2002, Riegl 2003, Riegl \& Piller 2003, McClanahan et al. 2007, RodríguezRamírez et al. 2008), it does not necessarily follow that this oceanographic process will generally have such beneficial consequences. Although a number of 
upwelling regions remain to be analysed, our case studies reveal important differences in the potential of upwelling in the mitigation of warming. Upwelling is unable to counteract thermal stress if there is asynchrony between upwelling and warming (e.g. Panama). In contrast, if upwelling and warming are synchronous-as occurred in 3 of the 4 case studies-then upwelling will only provide a thermal refuge during warming if it also decreases the strength or the duration of the warm season and thus the period of vulnerability to thermal anomalies. This was found to be the case in Colombia and Oman but not in Madagascar.

In addition to the modification of the thermal stress regime, upwelling is likely to influence 3 other factors that might mediate the bleaching response of corals: incoming light, food supply and aragonite saturation state (Mumby et al. 2001, Lesser \& Farrell 2004, Grottoli et al. 2006, Anthony et al. 2008, Baker et al. 2008). Upwelling draws nutrient-rich waters to the surface, promoting the growth of plankton and decreasing the penetration of light ( $\mathrm{D}^{\prime} \mathrm{Croz}$ \& Robertson 1997, Matthews et al. 2008). The reduction of light penetration leads to decreased radiative stress, potentially mitigating the negative synergistic effects of thermal and radiative stress in bleached corals (Lesser \& Farrell 2004, Enríquez et al. 2005). Furthermore, it has been speculated that increases in plankton abundance and therefore food supply account for faster rates of recovery after bleaching episodes in some upwelling areas (Salm \& Coles 2001, Wilkinson 2002). Upwelling, through the upward movement of deep water masses, is also likely to bring waters to the surface that have a

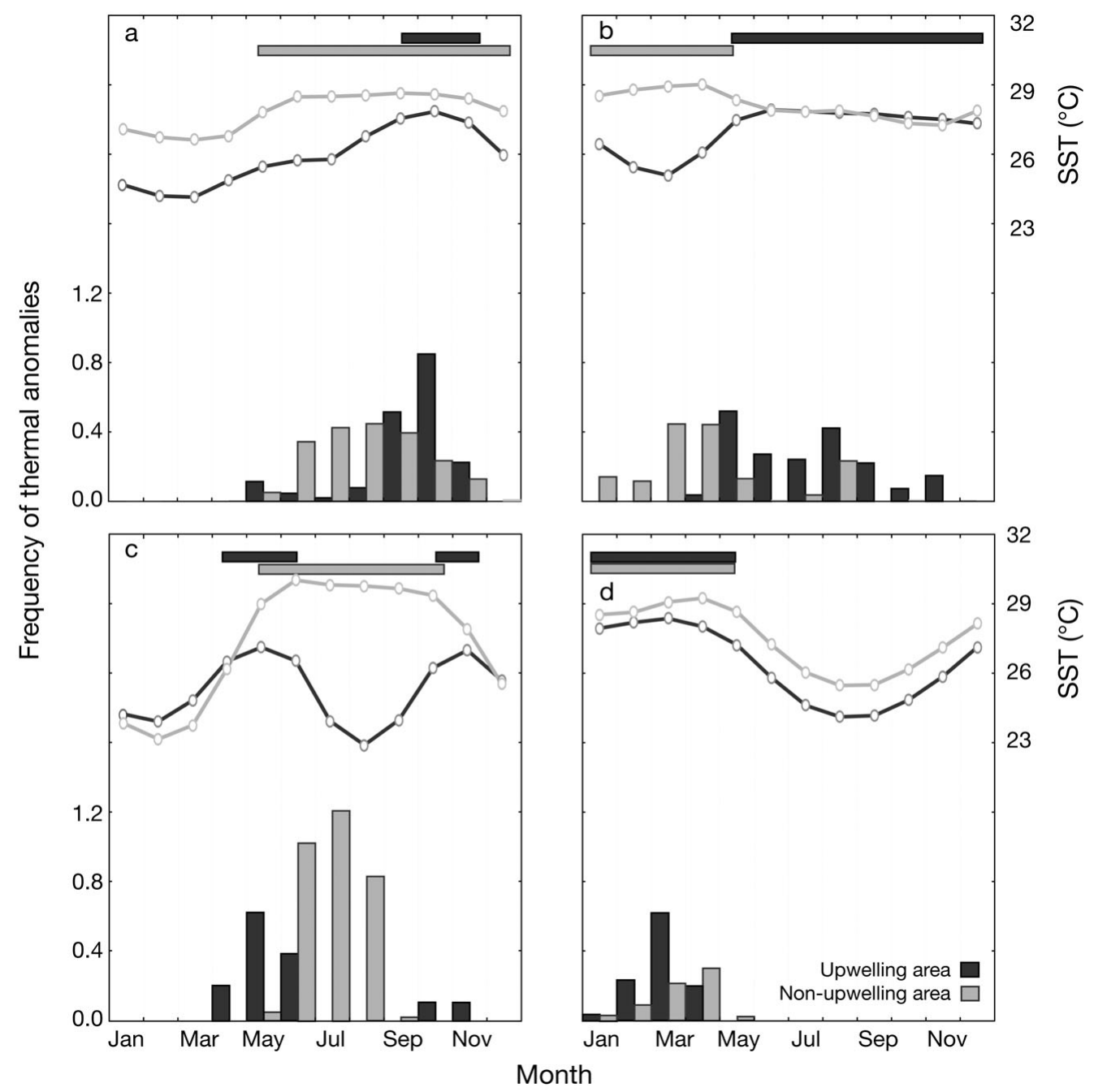

Fig. 3. Monthly distribution of temperature averages (lines) and frequency of thermal anomalous events (percentage of weeks when HotSpots exceeded $1^{\circ} \mathrm{C}$; bars) in upwelling and non-upwelling nearby areas in (a) Colombian Caribbean, (b) Pacific Panama, (c) Oman and (d) northern Madagascar. Horizontal lines highlight warm months in upwelling (dark gray) and nonupwelling (light gray) areas, when monthly temperatures were less than $1^{\circ} \mathrm{C}$ below the maximum monthly mean $(1985$ to 2005 AVHRR Pathfinder data). SST: sea surface temperature 
reduced aragonite saturation state (Feely et al. 2008, Manzello et al. 2008), potentially aggravating the effects of coral bleaching (Anthony et al. 2008). This implies that the same deeper water masses that are beneficial for coral reefs, bringing cool and turbid waters as a defence against bleaching and nutrients to satisfy their heterotrophic needs, could also contain a chemical hazard. Additional research is required into the geographic and temporal likelihood of this mechanism to provide a clear assessment of the strategic value of upwelling areas as a refuge from climate change.

Although the extent to which upwelling may mitigate bleaching impacts through enhanced heterotrophy and reduced solar radiation are not yet clear, these benefits are only likely to accrue when upwelling and warming are synchronous. Such effects would therefore be less likely in the eastern Pacific than in the other regions studied which had higher synchrony. Moreover, these non-thermal benefits may be particularly important in locations like Madagascar, where our analysis predicts the co-occurrence of upwelling and warming but no significant thermal protection.

The significance of upwelling regions as refuges for coral reefs will ultimately depend on their reliability in time. There is a large degree of uncertainty regarding the effects of climate change on upwelling intensity (Wang et al. 2010). While increases in wind stress and cooling have been observed in some of the main eastern boundary upwelling systems during the last few decades (Bakun 1990, Snyder et al. 2003, McGregor et al. 2007, Vargas et al. 2007), some evidence to the contrary also exists in which upwelling has decreased (Di Lorenzo et al. 2005). Such uncertainty in the future dynamics of upwelling should be borne in mind before any action is taken to stratify reef management activities on the basis of upwelling refugia from bleaching.

The incidence of upwelling and warming is variable on seasonal and interannual time scales. Our analysis of seasonal upwelling in 4 geographic locations concluded that synchrony between warming and upwelling is often high but does not necessarily confer a refuge from thermal stress. We recommend that management actions predicated on upwelling-based refugia consider both the synchrony and extent of the impact of upwelling on thermal stress. We also point out that while upwelling may confer benefits to reefs, in terms of reduced bleaching incidence, they have the potential to cause detrimental effects if aragonite saturation state is reduced and/or if elevated turbidity reduces rates of coral calcification to the extent that reef accretion ceases. In short, upwelling has the potential to benefit some reefs in the short term, but whether upwelling proves to be an 'ace up the sleeve' for reef conservation in the long term remains to be seen.
Acknowledgements. We thank the Higher Education Funding Council for England (HEFCE) through the ORSAS scheme, the University of Exeter, the GEF Coral Reef Targeted Research, and EU Future of Reefs in a Changing Environment (FORCE) for funding. We also thank the Vicerrectoría de Investigación, Universidad de Costa Rica (projects 808-98-013 and 808-A5-037) for additional financial support. S. Heron, W. Skirving and C. M. Eakin (Coral Reef Watch, NOAA) provided the weekly AVHRR Pathfinder product used for the SST analyses. We are also very grateful to C. M. Eakin, B. Riegl, E. Klein and 5 anonymous reviewers for valuable discussions.

\section{LITERATURE CITED}

Amador JA, Alfaro EJ, Lizano OG, Magaña VO (2006) Atmospheric forcing of the eastern tropical Pacific: a review. Prog Oceanogr 69:101-142

Andrade CA, Barton ED (2005) The Guajira upwelling system. Cont Shelf Res 25:1003-1022

- Anthony KRN, Kline DI, Díaz-Pulido G, Dove S, Hoegh-Guldberg $O$ (2008) Ocean acidification causes bleaching and productivity loss in coral reef builders. Proc Natl Acad Sci USA 105:17442-17446

Astor Y, Müller-Karger F, Scranton MI (2003) Seasonal and interannual variation in the hydrography of the Cariaco Basin: implications for basin ventilation. Cont Shelf Res 23:125-144

Baker AC, Glynn PW, Riegl B (2008) Climate change and coral reef bleaching: an ecological assessment of longterm impacts, recovery trends and future outlook. Estuar Coast Shelf Sci 80:435-471

Bakun A (1990) Global climate change and intensification of coastal ocean upwelling. Science 247:198-201

> Bograd SJ, Schroeder I, Sarkar N, Qiu XM, Sydeman WJ, Schwing FB (2009) Phenology of coastal upwelling in the California Current. Geophys Res Lett 36:L01602

> Bongaerts P, Ridgway T, Sampayo E, Hoegh-Guldberg O (2010) Assessing the 'deep reef refugia' hypothesis: focus on Caribbean reefs. Coral Reefs 29:309-327

Brown BE, Dunne RP, Chansang H (1996) Coral bleaching relative to elevated seawater temperature in the Andaman Sea (Indian Ocean) over the last 50 years. Coral Reefs 15:151-152

> Casey KS, Cornillon P (2001) Global and regional sea surface temperature trends. J Clim 14:3801-3818

Casey KS, Brandon TB, Cornillon P, Evans R (2010) The past, present and future of the AVHRR Pathfinder SST program. In: Barale V, Gower JVR, Alberotanza L (eds) Oceanography from space, revisited. Springer, New York, NY, p 273-288

Castillo K, Helmuth B (2005) Influence of thermal history on the response of Montastraea annularis to short-term temperature exposure. Mar Biol 148:261-270

Coles SL, Jokiel PL (1977) Effects of temperature on photosynthesis and respiration in hermatypic corals. Mar Biol 43:209-216

Coles SL, Jokiel PL, Lewis CR (1976) Thermal tolerance in tropical versus subtropical Pacific reef corals. Pac Sci 30:159-166

Connell JH (1978) Diversity in tropical rain forests and coral reefs. Science 199:1302-1310

D'Croz L, Robertson DR (1997) Coastal oceanographic conditions affecting coral reefs on both sides of the Isthmus of Panama. In: Lessios HA, Macintyre IG (eds) Proc 8th Int Coral Reef Symp. Smithsonian Tropical Research Institute, 
Panama City, p 2053-2058

D'Croz L, Maté JL, Oke JE (2001) Responses to elevated sea water temperature and UV radiation in the coral Porites lobata from upwelling and non-upwelling environments on the Pacific coast of Panama. Bull Mar Sci 69:203-214

Di Lorenzo E, Miller AJ, Schneider N, McWilliams JC (2005) The warming of the California current system: dynamics and ecosystem implications. J Phys Oceanogr 35:336-362

Díaz-Pulido G, Garzón-Ferreira J (2002) Seasonality in algal assemblages on upwelling-influenced coral reefs in the Colombian Caribbean. Bot Mar 45:284-292

Enríquez S, Méndez ER, Iglesias-Prieto R (2005) Multiple scattering on coral skeletons enhances light absorption by symbiotic algae. Limnol Oceanogr 50:1025-1032

Fabricius KE, Mieog JC, Colin PL, Idip D, Van Oppen MJH (2004) Identity and diversity of coral endosymbionts (zooxanthellae) from three Palauan reefs with contrasting bleaching, temperature and shading histories. Mol Ecol 13:2445-2458

Feely RA, Sabine CL, Hernandez-Ayon JM, Ianson D, Hales B (2008) Evidence for upwelling of corrosive 'acified' water onto the continental shelf. Science 320:1490-1492

Fortin MJ, Dale M (2005) Spatial analysis. A guide for ecologists. Cambridge University Press, Cambridge

Glynn PW (1993) Monsoonal upwelling and episodic Acanthaster predation as probable controls of coral reef distribution and community structure in Oman, Indian Ocean. Atoll Res Bull 379:1-66

> Glynn PW (1996) Coral reef bleaching: facts, hypotheses and implications. Glob Change Biol 2:495-509

Glynn PW, D'Croz L (1990) Experimental evidence for high temperature stress as the cause of El Niño-coincident coral mortality. Coral Reefs 8:181-191

Glynn PW, Leyte-Morales GEL (1997) Coral reefs of Huatulco, west Mexico: reef development in upwelling Gulf of Tehuantepec. Rev Biol Trop 45:1033-1047

> Glynn PW, Druffel EM, Dunbar RB (1983) A dead Central American coral reef tract: possible link with the little ice age. J Mar Res 41:605-637

Glynn PW, Cortés J, Guzmán HM, Richmond RH (1988) El Niño (1982-83) associated coral mortality and relationship to sea surface temperature deviations in the tropical eastern Pacific. In: Choat JH, Barnes D, Borowitzka MA, Coll JC and others (eds) Proc 6th Int Coral Reef Symp. Symposium Executive Committee, Townsville, p 237-243

Glynn PW, Maté JL, Baker AC, Calderón MO (2001) Coral bleaching and mortality in Panamá and Ecuador during the 1997-1998 El Niño-Southern oscillation event: spatial/ temporal patterns and comparisons with the 1982-1983 event. Bull Mar Sci 69:79-109

Good SA, Corlett GK, Remedios JJ, Noyes EJ, LlewellynJones DT (2007) The global trend in sea surface temperature from 20 years of advanced very high resolution radiometer data. J Clim 20:1255-1264

Goreau TJ, Hayes RL (1994) Coral bleaching and ocean hotspots. Ambio 23:176-180

> Goreau T, McClanahan T, Hayes R, Strong A (2000) Conservation of coral reefs after the 1998 global bleaching event. Conserv Biol 14:5-15

Grimsditch G, Salm RV (2005) Coral reef resilience and resistance to bleaching. The World Conservation Union, Gland

> Grottoli AG, Rodrigues LJ, Palardy JE (2006) Heterotrophic plasticity and resilience in bleached corals. Nature 440: 1186-1189

Hoegh-Guldberg O, Mumby PJ, Hooten AJ, Steneck RS and others (2007) Coral reefs under rapid climate change and ocean acidification. Science 318:1737-1742
Houlbrèque F, Ferrier-Pagès C (2009) Heterotrophy in tropical scleractinian corals. Biol Rev Camb Philos Soc 84:1-17

IPCC (Intergovernmental Panel on Climate Change) (2007) Climate change 2007: synthesis report. Contribution of Working Groups I, II and III to the Fourth Assessment Report of the Intergovernmental Panel on Climate Change. IPCC, Geneva

Jiménez C, Cortés J, León A, Ruiz E (2001) Coral bleaching and mortality associated with the 1997-98 El Niño in an upwelling environment in the Eastern Pacific (Gulf of Papagayo, Costa Rica). Bull Mar Sci 69:151-169

- Lesser MP, Farrell JH (2004) Exposure to solar radiation increases damage to both host tissues and algal symbionts of corals during thermal stress. Coral Reefs 23:367-377

Liu G, Strong AE, Skirving W, Arzayus LF (2006) Overview of NOAA coral reef watch program's near-real time satellite global coral bleaching monitoring activities. In: Suzuki Y, Nakamori T, Hidaka M, Kayanne $\mathrm{H}$ and others (eds) Proc 10th Int Coral Reef Symp. Okinawa Convention Center, Okinawa, p 1783-1793

Madin JS, Connolly SR (2006) Ecological consequences of major hydrodynamic disturbances on coral reefs. Nature 444:477-480

Manzello DP, Kleypas JA, Budd DA, Eakin CM, Glynn PW, Langdon C (2008) Poorly cemented coral reefs of the eastern tropical Pacific: possible insights into reef development in a high- $\mathrm{CO}_{2}$ world. Proc Natl Acad Sci USA 105: 10450-10455

Matthews KA, Grottoli AG, McDonough WF, Palardy JE (2008) Upwelling, species, and depth effects on coral skeletal cadmium-to-calcium ratios $(\mathrm{Cd} / \mathrm{Ca})$. Geochim Cosmochim Acta 72:4537-4550

- McClanahan TR, Ateweberhan M, Muhando CA, Maina J, Mohammed MS (2007) Effects of climate and seawater temperature variation on coral bleaching and mortality. Ecol Monogr 77:503-525

- McClanahan TR, Ateweberhan M, Omukoto J, Pearson L (2009) Recent seawater temperature histories, status, and predictions for Madagascar's coral reefs. Mar Ecol Prog Ser 380:117-128

> McGregor HV, Dima M, Fischer HW, Mulitza S (2007) Rapid 20th-century increase in coastal upwelling off northwest Africa. Science 315:637-639

McWilliams JP, Cotè IM, Gill JA, Sutherland WJ, Watkinson AR (2005) Accelerating impacts of temperature-induced coral bleaching in the Caribbean. Ecology 86:2055-2060

Mumby PJ, Chisholm JRM, Edwards AJ, Andréföuet S, Jaubert J (2001) Cloudy weather may have saved Society Island reef corals during the 1998 ENSO event. Mar Ecol Prog Ser 222:209-216

Nakamura T, van Woesik R (2001) Water-flow rates and passive diffusion partially explain differential survival of corals during the 1998 bleaching event. Mar Ecol Prog Ser 212:301-304

Nakamura T, Yamasaki H, van Woesik R (2003) Water flow facilitates recovery from bleaching in the coral Stylophora pistillata. Mar Ecol Prog Ser 256:287-291

Philander SG, Fedorov A (2003) Is El Niño sporadic or cyclic? Annu Rev Earth Planet Sci 31:579-594

Pickett S, White P (1986) The ecology of natural disturbance and patch dynamics, Vol xvi. Academic Press, Orlando, FL

Podestá GP, Glynn PW (2001) The 1997-98 El Niño event in Panama and Galapagos: an update of thermal stress indices relative to coral bleaching. Bull Mar Sci 69:43-59

Reyes-Bonilla H (2001) Effects of the 1997-1998 El NiñoSouthern Oscillation on coral communities of the Gulf of California, Mexico. Bull Mar Sci 69:251-266 
Reyes-Bonilla H, Carriquiry J, Leyte-Morales G, Cupul-Magaña A (2002) Effects of the El Niño-Southern Oscillation and the anti-El Niño event (1997-1999) on coral reefs of the western coast of México. Coral Reefs 21:368-372

Riegl B (2003) Climate change and coral reefs: different effects in two high-latitude areas (Arabian Gulf, South Africa). Coral Reefs 22:433-446

Riegl B, Piller WE (2003) Possible refugia for reefs in times of environmental stress. Int J Earth Sci 92:520-531

Rodríguez-Ramírez A, Bastidas C, Rodríguez S, Leão Z and others (2008) The effects of coral bleaching in southern tropical America: Brazil, Colombia and Venezuela. In: Wilkinson C, Souter D (eds) The status of Caribbean coral reefs after bleaching and hurricanes in 2005. Global Coral Reef Monitoring Network, and Reef and Rainforest Research Centre, Townsville, p 105-114

Sætre R (1985) Surface currents in the Mozambique channel. Deep-Sea Res A 32:1457-1467

Salm RV, Coles SL (2001) Coral bleaching and marine protected areas. The Nature Conservancy, Bishop Museum, Honolulu, HI

Shi W, Morrison JM, Böhm E, Manghnani V (2000) The Oman upwelling zone during 1993, 1994 and 1995. Deep-Sea Res II 47:1227-1247

Skirving W, Strong A, Liu G, Liu C, Arzayus F, Sapper J, Bayler E (2006) Extreme events and perturbations of coastal ecosystems: sea surface temperature change and coral bleaching. In: Richardson L, LeDrew E (eds) Remote sensing of aquatic coastal ecosystem processes. Kluwer, Amsterdam, p 11-25

Snyder MA, Sloan LC, Diffenbaugh NS, Bell JL (2003) Future climate change and upwelling in the California Current. Geophys Res Lett 30:1823

Strong A, Barrientos C, Duda C, Sapper J (1997) Improved satellite techniques for monitoring coral reef bleaching. In:

Editorial responsibility: Peter Edmunds,

Northridge, California, USA
Lessios HA, Macintyre IG (eds) Proc 8th Int Coral Reef Symp. Smithsonian Tropical Research Institute, Panama City, p 1495-1498

Sverdrup HU, Johnson MW, Fleming RW (1942) The oceans: their physics, chemistry and general biology. PrenticeHall, Englewood, NJ

> Ulstrup KE, Berkelmans R, Ralph PJ, van Oppen MJH (2006) Variation in bleaching sensitivity of two coral species across a latitudinal gradient on the Great Barrier Reef: the role of zooxanthellae. Mar Ecol Prog Ser 314:135-148

- Vargas G, Pantoja S, Rutllant JA, Lange CB, Ortlieb L (2007) Enhancement of coastal upwelling and interdecadal ENSO-like variability in the Peru-Chile Current since late 19th century. Geophys Res Lett 34:L13607

Wang CZ (2007) Variability of the Caribbean Low-Level Jet and its relations to climate. Clim Dyn 29:411-422

Wang C, Fiedler PC (2006) ENSO variability and the eastern tropical Pacific: a review. Prog Oceanogr 69:239-266

Wang M, Overland JE, Bond NA (2010) Climate projections for selected large marine ecosystems. J Mar Syst 79: 258-266

West JM, Salm RV (2003) Resistance and resilience to coral bleaching: implications for coral reef conservation and management. Conserv Biol 17:956-967

Wilkinson C (2002) Status of coral reefs of the world: 2002. Australian Institute of Marine Science, Townsville

Wilkinson C, Souter D (2008) Status of Caribbean coral reefs after bleaching and hurricanes in 2005. Global Coral Reef Monitoring Network, and Reef and Rainforest Research Centre, Townsville

Wilkinson C, Lindén O, Cesar H, Hodgson G, Rubens J, Strong AE (1999) Ecological and socioeconomic impacts of 1998 coral mortality in the Indian Ocean: an ENSO impact and a warning of future change? Ambio 28:188-196

Zar J (1999) Biostatistical analysis, 4th edn. Prentice Hall, NJ

Submitted: April 21, 2010; Accepted: August 18, 2010

Proofs received from author(s): September 27, 2010 